\title{
MAGEA4 wt Allele
}

National Cancer Institute

\section{Source}

National Cancer Institute. MAGEA4 wt Allele. NCI Thesaurus. Code C104513.

Human MAGEA4 wild-type allele is located in the vicinity of Xq28 and is approximately 13 $\mathrm{kb}$ in length. This allele, which encodes melanoma-associated antigen 4 protein, may play a role in embryonal development, tumor transformation, or tumor progression. 